\title{
THE FALLACY OF “EQUAL TREATMENT" IN BRAZIL'S BILL OF RIGHTS FOR INTERNET USERS
}

\author{
J. Gregory Sidak*
}

A FALÁCIA DA "IGUALDADE DE TRATAMENTO" NA CARTA BRASILEIRA

DE DIREITOS DOS USUÁRIOS DA INTERNET

\section{RESUMO}

A "CARTA brasileira de direitos dos usuários da InTERnet," OU "Marco CiVIL," tramita no Congresso brasileiro desde 2011 As DISPOSIÇÕES dO MARCO CIVIL RELATIVAS À NEUTRALIDADE DE REDE SÃO PARTICULARMENTE CONTROVERSAS. OS DEFENSORES DA NEUTRALIDADE DE REDE NO BRASIL ADVOGAM PELA "IgUALDADE DE TRATAMENTO" DE TODOS OS PACOTES DE DADOS, INCLUSIVE PROIBINDO QUE PROVEDORES DE SERVICCO DE ACESSO À INTERNET OFEREÇAM AOS PROVEDORES DE CONTEÚDO A OPÇÃO DE ADQUIRIR UMA MELHOR QUALIDADE DE SERVICCO NA ENTREGA DE PACOTES DE DADOS. ESSAS DISPOSIÇÕES RELATIVAS À NEUTRALIDADE DE REDE CONFLITAM COM OUTROS OBJETIVOS E PRINCÍPIOS DO MARCO CIVIL - ESPECIALMENTE OS OBJETIVOS DE PROMOVER O ACESSO À INTERNET, PROMOVER A INOVAÇÃO, E GARANTIR O DIREITO CONSTITUCIONAL DE LIBERDADE DE EXPRESSÃO E INFORMAÇÃO.

\section{PALAVRAS-CHAVE}

Telecomunicações; Regulação; Concorrência; Rede; Neutralidade de Rede; Bem-estar do consumidor; INTERNET; DISCRIMINAC̣ÃO; BANDA LARGa; INOVAÇÃO.

\begin{abstract}
THE "BRAZILIAN BILL OF RIGHTS FOR INTERNET USERS," or "MARco CIVIL," has beEN UNDER CONSIDERATION AT THE BRAZILIAN CONGRESS SINCE 2011. MARCO CIVIL'S PROVISIONS FOR NETWORK NEUTRALITY HAVE BEEN PARTICULARLY CONTROVERSIAL. PROPONENTS OF NETWORK NEUTRALITY IN BRAZIL ADVOCATE FOR THE "EQUAL TREATMENT" OF ALL DATA PACKETS, INCLUDING BANNING INTERNET SERVICE PROVIDERS FROM OFFERING TO CONTENT PROVIDERS THE OPTION TO PURCHASE ENHANCED QUALITY OF SERVICE IN THE DELIVERY OF DATA PACKETS. THESE NETWORK NEUTRALITY RULES CONFLICT WITH THE OTHER GOALS AND PRINCIPLES OF MARCO CIVIL-PARTICULARLY GOALS TO PROMOTE INTERNET ACCESS, TO FOSTER INNOVATION, AND TO PROTECT THE CONSTITUTIONAL RIGHT OF FREEDOM OF SPEECH AND THE FREE FLOW OF INFORMATION.
\end{abstract}

\section{KEYWORDS}

TELECOMMUNICATIONS; REgULATION; COMPETITION; Network; Network Neutrality; Consumer Welfare; INTERNET; DISCRIMINATION; BROADBAND; INNOVATION.

\section{INTRODUCTION}

An inaccurate assessment by Lawrence Lessig in $2001^{1}$ was perhaps the first marker of the new battle in telecommunications regulation centered on an arcane notion dubbed "network neutrality." Lessig proclaimed that "[t]he internet revolution has ended just as surprisingly as it began. None expected the explosion of creativity that the network produced; few expected that explosion to collapse as quickly and profoundly as it has." 2 Soon arguments of other advocates and opponents of "network 
neutrality" came into prominence and the network neutrality debate unfolded in other nations. ${ }^{3}$

The pivotal advocates of network neutrality regulation, Lawrence Lessig ${ }^{4}$ and Tim $\mathrm{Wu},{ }^{5}$ propounded several key assumptions underlying their arguments for network neutrality. These assumptions have remained a persistent refrain among proponents of network neutrality in different jurisdictions. ${ }^{6}$ The first is the assumption that the broadband Internet access service provider ("ISP") has monopoly power. The second is the normative judgment that innovation "at the edges" of the network (that is, Internet applications and content) is more virtuous than innovation within the core of the network (that is, network infrastructure). The third is that, absent network neutrality regulation, network operators would use the threat of degraded best-effort service quality to force content and application providers to pay for prioritized delivery. Lessig and $\mathrm{Wu}$ thus speculated that priority delivery would lead to anticompetitive discrimination.

The arguments put forth by the proponents of network neutrality prompted critique from leading economists, technologists, and legal scholars, including Christopher Yoo, ${ }^{7}$ William Baumol, ${ }^{8}$ Dennis Carlton, ${ }^{9}$ Gary Becker, ${ }^{10}$ Richard Epstein, ${ }^{11}$ Alfred Kahn, ${ }^{12}$ and Bruce Owen. ${ }^{13}$ I have also published work and testified against network neutrality regulation of the Internet. ${ }^{14}$ These scholars have demonstrated that arguments in favor of network neutrality lack empirical support; rest on a misguided focus on only one component of social welfare - content provider welfare - rather total welfare; fail to account for the impacts of customer choice, two-sided markets, competition, and innovation within the network; and disregard the obvious costs of regulation and the availability of antitrust law to remedy anticompetitive behavior. ${ }^{15}$

In Brazil, the lack of legislation governing the use of Internet led the Brazilian Ministry of Justice, in partnership with Fundação Getulio Vargas do Rio de Janeiro (Center for Technology and Society of FGV-RJ), to launch in 2009 a project to draft the preliminary text of a "Brazilian Bill of rights for Internet users" (the so-called "Marco Civil"). This bill would establish the rights and duties of Internet end users, content providers, and access providers. In 2011, Marco Civil was introduced for consideration by the Brazilian Congress. ${ }^{16}$ Marco Civil encompasses several Internet issues, including online privacy, torts committed on the Internet, and a regime of network neutrality. Controversy over the network neutrality provisions have delayed the voting of the Bill. ${ }^{17}$ In the past months, the rules on network neutrality have given rise to debates among Brazilian scholars, ISPs, Internet content providers, associations of end users, and the Brazilian government.

The proponents of a Brazilian net neutrality regime have invoked the theories advanced by $\mathrm{Wu}$ and Lessig, sharing a utopian view of technology and a dystopian view of the private ordering of economic activity. According to proponents of network neutrality in Brazil, competition in Brazil's broadband Internet access market 
is limited due to the presence of an ISP with market power. ${ }^{18}$ Therefore, according to the proponents, ensuring network neutrality is essential to guarantee that content providers will be treated equally and that ISPs will not hinder innovation at the edges of the network. ${ }^{19}$

Proponents of network neutrality in Brazil essentially have three objectives. First, proponents of network neutrality seek to prohibit ISPs from contracting with content or application providers for speedier delivery of content, or enhanced QoS, on the local access network (otherwise known as "access tiering"). They argue that access tiering would increase barriers to entry in the market for Internet content, limiting competition and innovation in Internet content. ${ }^{20}$ Furthermore, they claim that ISPs would intentionally degrade their best-effort delivery of packets to force content providers to buy prioritized delivery of packets. ${ }^{21}$ Proponents also argue that access tiering would mean penalizing content providers that have "good traffic." 22 If end users want faster delivery of content, proponents argue, end users should pay higher prices, since end users are the ones who actually use the content and applications. ${ }^{23}$

Second, proponents seek to prohibit ISPs from blocking content or applications. They argue that ISPs have an incentive to discriminate against content providers and block applications contrary to their interests. They thus invoke network neutrality as a necessary means to guarantee that all content is treated equally. ${ }^{24}$ The premise of this argument is that ISPs would discriminate or block content and applications that are bandwidth-intensive or that compete with their own content. ${ }^{25}$

Third, proponents seek to constrain the ability of ISPs from integrating vertically into the production of content or applications. They argue that permitting network operators to integrate downstream into content and applications would create the incentive to foreclose competing content from their networks, thereby reducing competition and innovation. ${ }^{26}$

Opponents of a Brazilian network neutrality regime have explained that the proposed network neutrality regulation relies on incorrect assumptions about congestion management, innovation, competition, and consumer choice. ${ }^{27}$ They argue that preventing network operators from managing the use of bandwidth would hinder the efficient allocation of a scarce resource (bandwidth). Consequently, the cost of delivering data packets and the price of Internet access would rise. Prohibiting network operators from managing their networks would also deter innovation within the core of the network, which would ultimately reduce innovation at the edges of the network. ${ }^{28}$ Moreover, critics emphasize that the posited discrimination or foreclosure harms can be addressed with adequate, tailored remedies that already exist in Brazilian antitrust law and telecommunications legislation. ${ }^{29}$

The debate over a "Brazilian Bill of Rights for Internet users" has gained momentum since 2009 due to a presumed conflict between the growth of online communication and the lack of specific rules governing the use of the Internet in 
Brazil. The Ministry of Justice and FGV-RJ launched a project to draft a bill that would define and protect the rights of Internet users, emphasizing the expressive rights guaranteed by the Brazilian Constitution. The fundamental goals and principles underlying Marco Civil include protecting the constitutional rights of free speech and free flow of information, promoting the right of access to the Internet, promoting innovation, and guaranteeing network neutrality. ${ }^{30}$

Under article 9 of Marco Civil, "network neutrality” is defined as the ISPs' duty to grant "equal treatment" to every data packet, regardless of the "content, origin and destination, service, terminal or application." ${ }^{1}$ The Bill would prohibit ISPs from contracting with Internet content providers for faster delivery of content on the access network for a differentiated price. The Bill would also constrain the ability of ISPs to vertically integrate with content providers. Paragraph 3 of Article 9 prohibits blocking of content or applications.

Would a policy of network neutrality — defined in this context to be synonymous with "equal treatment" of all data packets - achieve or undermine the goals of Marco Civil? I analyze whether the proposed "equal treatment" rule would have the unintended consequences of compromising the inclusiveness of the network, reducing innovation both at the edges of the Internet and within the core, and diminishing consumer welfare in Brazil. Part II explains the complementary demand for Internet access by end users and content providers, an essential concept for understanding the network neutrality debate. Part III addresses the claim that access tiering would increase barriers to entry and would lead to a "dirt road" for content providers who do not purchase priority delivery. Part IV examines whether ISPs have the incentive or ability to use access tiering to harm competition by discriminating against content providers. PartV evaluates the common proposal that end users - instead of content providers - pay for faster delivery. Part VI explains how equal treatment of data packets in the proposed network neutrality regime would undermine the goals and principles of Marco Civil.

\section{Complementary Demand for InTernet Access}

Broadband access services have joint demand: Internet content providers supply their content and applications on the Internet, and end users demand access to the Internet to use content and applications. In a "two-sided" market of this sort, the demand that one party has for the product is complementary to the demand that the other party has for the same product. ${ }^{32}$ In this way, an ISP's network can be considered an intermediary that brings together two parties - the end user and the content provider - to an exchange that occurs over the Internet.

Understanding the complementary demand of end users and content providers for Internet access is essential to properly analyzing the extent to which ISPs have 
any incentive to engage in activities or conduct that would harm content providers. ISPs rely on Internet content to attract end users to subscribe to their networks. Innovations in content and application thus drive demand for Internet access. Email was the first "killer application" that generated the demand for dial-up Internet access. At the same time, ISPs' investments in network infrastructure support new content and applications. Downloading graphics-intensive images and video was made possible by broadband connections, which have been replacing dial-up access in many regions of the world.

A recurring theme in addressing proponents' arguments for network neutrality regulations is that they fail to account for the complementary demand for Internet access by content providers and end users. Consequently, proponents have often made exaggerated predictions about ISPs destroying creativity and innovation on the Internet. Over ten years after Lessig's prediction that the Internet revolution would collapse, one observes continued growth and innovation in Internet content and applications. This outcome should not be surprising, because it is in the economic interests of ISPs to foster innovation at the edges of the network.

\section{The Incorrect Arguments That Permitting Access Tiering Would Reduce InNOVATION}

ISPs deliver data packets using a "best-effort" quality of service (QoS) standard. Absent an "equal treatment" law in Brazil, an ISP could also provide "enhanced" QoS, which prioritizes the delivery of certain packets over others, guaranteeing a certain level of performance to a data flow. The proponents of network neutrality regulations in Brazil claim that permitting access tiering would threaten innovation by creating a barrier to entry in Internet content - in the form of the price for enhanced QoS. Even if content providers do not need enhanced QoS, proponents argue, ISPs would degrade the quality of best-effort QoS to force those content providers to purchase enhanced QoS. Those predictions are baseless.

\section{A. Will Fees for Access Tiering Create Barriers to Entry?}

Proponents of network neutrality regulation have argued that access tiering — specifically, content providers entering into voluntary business-to-business transactions with ISPs for enhanced QoS - would create barriers to entry in the market for Internet content by raising content providers' costs. ${ }^{33}$ Proponents further speculate that ISPs would fail to internalize the spillover benefits of content creation, and they would thus set enhanced QoS prices above "socially optimal" levels. ${ }^{34}$ However, neither empirical evidence nor economic theory supports those assumptions. To the contrary, economic theory indicates that access tiering would foster innovation. 


\section{i. Multiple Mechanisms for Funding Investments}

in Content and Applications

Proponents of an "equal treatment" rule argue that permitting optional business-tobusiness transactions for enhanced QoS would raise the cost of content and applications providers, which would cause suboptimal entry and investment at the edges of the network. However cash flow is a challenge for any start up-from the seller of street hot dogs to the provider of Internet applications and content, and not unique to the latter. If a content provider needs to purchase enhanced QoS, that cost becomes a cost of business — not a barrier to entry.

It is not credible that Internet content providers lack the funding to invest in innovations and to purchase inputs such as enhanced QoS. Content providers have multiple means of funding. First, funding can be generated by the internal cash flow of existing suppliers of content and application. Second, funding can come from direct or indirect government subsidies and programs for innovative activities provided by non-governmental organizations, such as the Brazilian Support Service for Micro and Small Enterprises (SEBRAE). ${ }^{35}$ Third, funding can come from the capital markets or other firms (including those above or below in the vertical chain of distribution). Venture capitalists specialize in funding innovative startups and in assessing their risk-return characteristics. ${ }^{36}$ In the United States, more than 40 percent of total venture capital investments were allocated to software, IT services, or computers and peripherals in the first three quarters of 2012. ${ }^{37}$ This level of investment refutes the lack-of-cash-flow arguments ${ }^{38}$ made by the proponents of access tiering. ${ }^{39}$ The cost of enhanced QoS is simply an additional cost of doing business, which should not prevent any content provider with a promising innovation from entering the market or investing.

Of course, for content and applications providers that do not need to purchase enhanced QoS, it is implausible that having the option to purchase QoS enhancements would deter them from producing new products. Not all content providers need enhanced QoS. In fact, empirical evidence suggests that broadband users in Brazil have not been using the available broadband connection speeds at full capacity. Although the maximum speed advertised by ISPs was roughly $100 \mathrm{Mbps}$, the average connection speed in 2011 was 1.8 Mbps. ${ }^{40}$ Common Internet applications operate efficiently at speeds far slower than best-effort speeds. For example, sending an email requires minimal bandwidth, of around $15 \mathrm{kbps}$ without attachments. Streaming CD-quality audio requires less than $350 \mathrm{Kbps} ;{ }^{41}$ VoIP requires around $64 \mathrm{Kbps} ;{ }^{42}$ video conferencing requires $900 \mathrm{Kbps} .{ }^{43}$

Given the fact that few Internet applications currently would need enhanced QoS, ${ }^{44}$ and the fact that the default best-effort QoS is more than sufficient for many applications, it is hard to fathom that the option to purchase enhanced QoS would significantly change the market dynamics of Internet content. Because ISPs will still 
use their best-effort delivery speed, content providers that do not need enhanced delivery will not experience a decrease in QoS. Moreover, best-effort delivery speeds will likely continue to increase as ISPs continue to invest in their networks. ${ }^{45}$ Hence, a content provider that does not contract for enhanced QoS cannot be harmed in any absolute sense. Thus, content providers that do not need enhanced QoS will not face increased costs, let alone increased barriers to entry.

\section{Internalization of Positive Spillovers in the Prices for Enhanced QoS}

Proponents of the "equal treatment" rule have focused on the effects of optional business-to-business transactions for enhanced QoS on positive spillovers created by Internet content and applications. Positive spillovers, or externalities, are benefits that accrue as unpriced side effects of other actions of an individual or firm. Investments and innovation by content providers - as well as by network operators-yield consumer surplus that neither the content providers nor the network operators fully capture in their charges.

Proponents of network neutrality in Brazil argue that ISPs would fail to internalize the positive spillovers from Internet content in pricing QoS enhancements. That is, ISPs would charge prices for enhanced QoS above optimal levels that fail to account for positive spillovers. Consequently, the resulting high costs of enhanced QoS would discourage innovation in Internet content, which would reduce positive spillovers accruing from Internet content.

There is no general incentive for ISPs to implement practices that would reduce the supply of Internet content or diminish the positive spillovers associated with Internet content. Given the strong complementarity of demand for Internet access and content, network operators have no incentive to harm innovation in Internet content, because to do so would harm the demand for broadband access. Clearly, ISPs have a great incentive to attract new, innovative content and applications to their networks and therefore to set prices for enhanced QoS at levels that reflect the positive spillovers of Internet content. This logic, formalized by Joseph Farrell and Philip Weiser in their development of the concept of "internalization of complementary efficiencies" (ICE) holds even in a market with a monopolist ISP. ${ }^{46}$ Rivalry between network operators--for example, cable broadband and DSL providers - further enhance this incentive. Positive externalities from innovation in content and applications thus accrue to ISPs - not only to Internet end users. Consequently, ISPs have an incentive to encourage entry and innovation in content and applications and their concomitant positive spillovers.

Finally, positive externalities from Internet content are not the only positive spillovers from the Internet. Positive spillovers also accrue from the core of the network - that is, the network itself. When an ISP invests in bandwidth or efficient routing to improve its services, those investments benefit not only end users, but 
also content providers. If an excessively high price for enhanced QoS would threaten positive spillovers from Internet content, an excessively low price for enhanced QoS — that is, the price of zero advocated by network neutrality proponents — would discourage investment in network infrastructure. A suboptimal level of network investment and innovation would constrain the ability of content providers to develop and supply new applications.

\section{B. Would Access Tiering Harm Content Providers That Do Not Need Enhanced QoS?}

Brazilian proponents of network neutrality have embraced the so-called "dirt road" metaphor coined by Lessig and McChesney, ${ }^{47}$ which claims that the ability of ISPs to sell enhanced QoS would create an incentive among ISPs to create a "dirt road," or slow lane, for best-effort content delivery. ${ }^{48}$ The argument is that ISPs would degrade or refuse to invest in the "slow lane" to induce content providers - who otherwise would not purchase enhanced QoS - to purchase access to its fast lane.

As a factual matter, this argument relies on a mischaracterization of the Internet as split between a "fast lane" superhighway reserved for enhanced QoS delivery and a "slow lane" for best-effort delivery subject to targeted degrading. As a matter of economic analysis, the "dirt road" theory relies on incorrect assumptions.

First, the "dirt road" theory depends on there being only a monopoly provider of Internet access in Brazil. It is not realistic to assume that any firm operating in a competitive market would expect to benefit by degrading the quality of its service. In the broadband access market, increasing network congestion would induce consumers to switch networks. In the past years, the supply of broadband appears to have become increasingly competitive - especially in major cities with large populations. For example, DSL operators have consistently lost market share to cable operators since 2008, ${ }^{49}$ indicating the ability of end users to switch ISPs if they are unsatisfied with their service. Substitution among ISPs eliminates their ability to profit from degrading best-effort QoS.

Second, the "dirt road" theory incorrectly presumes that the revenues an ISP would gain from QoS enhancements would far surpass gains from investing in improving the capacity and functionality of its best-effort platform. That outcome is extremely unlikely. As noted before, Internet access and content are complementary services. ISPs increase network value in part by ensuring that customers who purchase their services can access a wide variety of content and applications with satisfactory quality of service. If an ISP were to create a "dirt road" for content providers who choose not to purchase enhanced QoS, it would reduce the perceived end-user quality of its service, thereby diminishing the value of its network. The principle of ICE ensures that even a monopolist ISP would have the incentive to upgrade its network so that complementary content and application services can be 
"cheaply, innovatively and efficiently supplied." 0 So, even a monopoly ISP generally has no incentive to degrade the service quality for content providers that would not purchase enhanced QoS.

Third, for degrading best-effort QoS to be profitable and for the "dirt road" theory to be plausible, ISPs would need to be able to foreclose content and applications. This assumption is implausible because the geographic market for Internet content is not local or even national, but global. In addition, consumers are not "single-homed" — rather, many of them have broadband connections at home, cybercafés (Brazilian "lan houses"), work, and school, as well as through mobile devices. Consequently, no network operator can foreclose content to even a small fraction of end users. ISPs surely know that "content is king" and that any network operator that did degrade the delivery of content would suffer defections in a marketplace.

Finally, the empirical evidence confirms that Brazilian ISPs have, in fact, been investing billions of dollars annually to increase the speed and improve the quality of best-effort delivery service. ${ }^{51}$ That outcome is exactly what economic theory would predict under real-world conditions of platform competition, a global market for content and applications, and complementary demand between content availability and performance of broadband Internet access services. If ISPs were to relegate traffic from content and applications providers who did not choose to pay for enhanced QoS to a dirt road, they would risk losing subscribers.

\section{IV.The Unfounded Prediction That Vertically Integrated ISPS Would Use Access Tiering to Reduce Competition}

Brazilian proponents of network neutrality have put forward an additional argument in favor of the "equal treatment" regime, which concerns competition in the market for Internet content. They claim that vertically integrated ISPs would use access tiering to discriminate against or block competing content or applications. ${ }^{52}$ However, once more, neither empirical evidence nor economic theory supports those arguments.

\section{A. Flaws in Proponents' Foreclosure Theory of Harm}

The proponents of net neutrality regulation in Brazil assume that vertically integrated ISPs have the incentive and ability to block content and applications from the Internet - especially content and applications that compete with their affiliated content. As a matter of economic analysis, vertically integrated ISPs would not have the incentive to block lawful content from their networks. As detailed in Part II, content and applications are complementary to usage of the Internet access network. It is a well-established economic principle that if the demand for product $A$ (here Internet access) increases with the demand for product $B$ (here Internet content 
and applications), then even a monopoly provider of $A$ would have no incentive to harm the demand for $B$. ISPs thus have no incentive to reduce demand for Internet content, applications, or devices. To do so would reduce demand for broadband access. The complementary demand for Internet access and content obviates a ban on business-to-business transactions for QoS.

ISPs in Brazil have invested billions of dollars in upgrades to the best-effort platform and in new technologies, such as $3 \mathrm{G}^{53}$ One goal of these investments is to provide enhanced QoS for new real-time applications. It would be foolish for a network operator to stymie the development of, and demand for, content and applications; doing so would squander billions of dollars in sunk investments. Thus, even in a market with a monopolist ISP, there is no incentive to block lawful applications. ${ }^{54}$

\section{B. The Effect of Competition on ISPs' Willingness to Foreclose Competing Content and Applications}

Even assuming that vertical integration is prevalent in Brazil's ISP market, the foreclosure theory is flawed. It depends upon the existence of monopoly power in the market for broadband access, which broadband ISPs in Brazil generally do not have. In fact, many Brazilians Internet users are located in large metropolitan centers with multiple, competing ISPS. ${ }^{5}$ ISPs similarly lack monopoly power in the market for content and applications, a market that is global in scope. ISPs thus cannot profitably foreclose access to Internet content. ${ }^{56}$ Moreover, as a result of the complementary nature of demand for Internet access and content, ISPs have strong incentives to promote inclusion of content and applications on their networks to attract more subscribers.

In markets with competing ISPs, such Brazil's large population centers - for example, Sao Paulo, Rio de Janeiro, and Salvador ${ }^{5}$ _ an ISP has no economic incentive to constrain a customer's ability to access a particular application, even if it is a substitute for an application that the ISP also offers to subscribers. In broadband access markets, each ISP competes for the others' customers by striving to offer a better quality experience to consumers. Because consumers can switch from one ISP to another — including from DSL to cable modem service-ISPs have limited ability to profit from blocking lawful, competing applications.

Potential entry from a variety of broadband access technologies - for example, optical fiber, Wimax, and satellite_-and competing ISPs expected in smaller Brazilian cities in the coming years further constrains the incentives of ISPs to block or degrade content and applications. ${ }^{58}$ For example, "Plano Nacional de Banda Larga," launched by the government in 2010, aims to popularize broadband Internet access by creating incentives for entrant and incumbent ISPs to use the public fiber optic network to provide Internet access, and by providing subsidies to the construction of private broadband networks. This plan has been accredited with increasing in two years the number of broadband subscriptions from 27 million to 70 million, ${ }^{59}$ with 
growth in subscriptions particularly large in small cities. ${ }^{60}$ Such measures increase potential competition faced by any monopolist ISP, which limits the ability of any ISP to profit from foreclosing competing content and applications in the long run.

Contrary to the predictions of network neutrality proponents, in the past years, it appears that competition in broadband access has increased-despite the absence of network neutrality regulations. Broadband prices have fallen while subscriptions have substantially increased. ${ }^{61}$ For example, from 2006 to 2011, the average price for $1 \mathrm{Mbps}$ service fell from R\$125.00 per month to R $\$ 65.00$ per month. ${ }^{62}$ The country-wide subscriptions for broadband service increased from 5.7 million $^{63}$ to 18.5 million subscriptions. ${ }^{64}$ In addition, global IP traffic has reportedly increased eightfold over the past five years and is expected to increase nearly fourfold over the next five years, ${ }^{65}$ thus permitting Internet users to enjoy more differentiated tools of Internet communication and information. According to a 2012 forecast by Cisco, the amount of new videos added to the Internet every day is so large that "it would take over 6 million years to watch the amount of video that will cross global IP networks each month in 2016."66 The growth in Internet content will help drive demand for and competition in providing affordable, high-quality Internet access.

Finally, the theory of vertical foreclosure fails to incorporate the dynamic nature of competition and innovation in the market for Internet access services. For the predictions of vertical foreclosure to hold, vertically integrated ISPs would need to be sure that they could generate their own successive waves of content or applications that could surpass the performance of all rival content or applications on the basis of quality, price, and consumer preference. In a dynamic, global market such as Internet content, it is doubtful that a single ISP could achieve that. The fear of future obsolescence in the dynamically competitive market for Internet content and applications overrules any incentive an ISP might have to engage in such foreclosure. The inevitable advent of new, improved services makes it extremely unlikely that an ISP would foreclose its network to unaffiliated content and application providers - and risk losing future subscribers who would switch to broadband networks supporting the next generation of content or applications-merely in the hope of extracting monopoly rents in the present. 67

\section{Addressing Anticompetitive Conduct with Tailored Antitrust Remedies}

Even under the assumption that an ISP could use access tiering anticompetitively, the proposed "equal treatment" rule is an overbroad remedy for the posited antitrust harm. First, tailored remedies already exist in Brazilian antitrust law ${ }^{68}$ and telecommunications legislation ${ }^{69}$ to deter ISPs from foreclosing or degrading the content or application of unaffiliated content providers. Consequently, any call for regulation on this ground must first demonstrate some reason why the posited harm will not be sufficiently deterred by the existing antitrust remedies and regulations. 
Second, proponents of network neutrality ignore the reality that ISPs differ substantially in the degree to which they are vertically integrated into the production of content or applications. Many ISPs, such as the Brazilian GVT, ${ }^{70}$ are vertically integrated only in very limited respects into content or applications, and thus do not have any incentive to foreclose customer-valued content or applications from their networks outside of those limited areas. The "equal treatment" rule, however, would apply to every ISP, even an entrant ISP that is not vertically integrated into downstream content. Banning access tiering as a means to prevent foreclosure by certain vertically integrated ISPs would be an overbroad regulation not tailored to fit the supposed problem. ${ }^{71}$

\section{Should Content Providers or End User Pay for Enhanced QoS?}

Some proponents of network neutrality in Brazil argue that end users should pay for enhanced QoS, because they are the ones who actually consume enhanced QoS. The presumption that only end users "consume" enhanced QoS is incorrect and misleading. A content provider whose content or applications are noticeably improved by a delivery speed above best-effort speed values enhanced QoS. If the quality of an application such as real-time video conferencing would noticeably improve from enhanced QoS, both the end user and the application provider are willing to pay for this service. Specifically, the content provider benefits from increased demand for its product as a result of the improved end user experience.

\section{A. Increased Economic Efficiency from Content Providers PAYING FOR ENHANCEd QoS}

Given that both end users and content providers value enhanced QoS, who should pay for enhanced QoS? Content providers are in a better position than end users to pay for enhanced QoS. First, ISPs can achieve lower transactions costs by contracting with content providers for enhanced QoS rather than end users, because there are significantly fewer content providers than end users, and therefore fewer negotiations required to provide the efficient amount of enhanced QoS.

Second, end users have high uncertainty regarding which applications they will use and which applications will require enhanced QoS. In contrast, content providers have a better understanding of whether the applications they offer require real-time delivery. End users' uncertainty about which applications require enhanced QoS will lead to inefficient allocation of resources. End users may purchase enhanced QoS when it is not needed, leading to wasted expenditures, or they may fail to purchase enhanced QoS when it is needed, leading to a deteriorated user experience with certain applications.

Third, the economic principle of Ramsey pricing shows why charging content providers instead of end users for enhanced QoS would be socially optimal. The cost 
to the ISP of providing enhanced QoS is a common cost: both content providers and end users consume enhanced QoS. It is therefore appropriate for end users and content providers to at least share that common cost. Should content providers or end users bear the greater share (or the entire share) of the common cost of providing enhanced QoS? Ramsey pricing teaches that those who are less price sensitive should pay a greater share of the common cost for enhanced QoS. ${ }^{72}$ It is more plausible that content providers are less sensitive to the price of enhanced QoS, because the quality of - and therefore the demand for-their products will depend on having enhanced QoS if they are highly sensitive to latency. For example, a provider of realtime healthcare monitoring likely has a high and inelastic willingness to pay for enhanced QoS. Thus, it is optimal for content providers that have demand for enhanced QoS to pay for enhanced QoS, not end users.

\section{B. Consumer-Welfare Gains from Permitting Content Providers to Pay for Enhanced QoS}

Permitting content providers to pay for enhanced QoS would increase consumer welfare, partly by leading to lower subscription prices. Because content providers are better positioned than end users to pay for enhanced QoS, they will purchase more enhanced QoS than end users would. Because content providers likely have higher willingness to pay for enhanced QoS than end users, content providers would also be willing to pay a higher price for enhanced QoS than end users. Consequently, fees for enhanced QoS from content providers would contribute more towards ISPs' recovery of sunk costs than hypothetical fees from end users. ISPs could use additional revenues from enhanced QoS to subsidize lower prices to end users. Brazilian consumers already using the Internet would benefit from lower prices and increased usage, and Brazilian consumers who previously could not afford subscriptions would gain Internet access.

The above benefits to consumers would be lost if only end users could pay for enhanced QoS. Requiring end users to pay for enhanced QoS would increase the cost of broadband subscriptions to consumers in Brazil. As a consequence of higher subscription prices, marginal consumers - with lower willingness to pay, such as poorer consumers - would be priced out of the market. Due to Brazil's large degree of income inequality, this group of consumers who would stop using the Internet could be substantial. As of 2009, the lowest 20 percent of the Brazilian population in terms of income owned only 2.9 percent of the nation's income. ${ }^{73}$ Brazil had a Gini index (a measure of income inequality between 0 and 100, with the level of income inequality rising with the magnitude of the index) of 54.7 as of 2009. ${ }^{74}$ Marginal consumers, who could no longer afford to access the Internet after a price increase, would forgo the positive spillovers associated with Internet content and applications. Unlike end users, content providers can obtain outside funding if they do not have the internal cash flow to pay for enhanced QoS. Forcing end users to pay for enhanced QoS would 
lower consumer welfare in Brazil and constrain Brazilian consumers' freedoms to access to the Internet.

Requiring end users to pay for enhanced QoS would also reduce positive network externalities. ${ }^{75}$ Positive network externalities are benefits to society that accrue as the size of a network grows. For example, an individual's demand to use (and hence her benefit from) a telephone network increases with the number of other users on the network whom she can call or from whom she can receive calls. ${ }^{76}$ Some telecommunications regulations, such as policies promoting universal service, are justified as a means to capture for consumers the benefits of network externalities that accrue as the size of the network grows. ${ }^{77}$

This economic relationship has substantial implications for the network neutrality debate in Brazil. It is essential that legislators adequately consider the positive network effects that could be eliminated by potential regulatory actions. In terms of the proposed network neutrality regulations, pricing policies that increase the size of the broadband Internet network should be encouraged, not prohibited. However, requiring end users to pay for enhanced QoS would raise broadband prices above levels that could be achieved if content providers paid for enhanced QoS. Shifting the cost of QoS enhancements to end users would thus impeded growth of the network and attainment of universal service, diminishing positive network effects. In contrast, the ability of charging content providers for optional QoS enhancements to increase the size of the broadband network weighs against a ban on optional businessto-business transactions for enhanced QoS.

In short, there is no logical or economic reason why end users should cover all the costs of the network when both end users and content providers benefit from its use. By charging content providers for enhanced QoS, a broadband service provider can recover sunk costs, reduce prices to consumers, and subsidize access to more price-sensitive customers, thereby increasing overall broadband penetration and the positive spillovers from the Internet.

\section{Vi. Will Equal Treatment Achieve or Undermine the Goals and Principles of Marco Civil?}

The fundamental goals and principles underlying Marco Civil include promoting consumer's "Internet freedoms," consisting of access to the Internet; ${ }^{78}$ promoting freedom of speech $^{79}$ and the free flow of information; ${ }^{80}$ fostering innovation; 81 and guaranteeing network neutrality. ${ }^{82}$ Proponents of network neutrality in Brazil justify a ban on access tiering as means to foster the former three goals and principles. However, as I explain below, ascribing importance to network neutrality — or an "equal treatment" rule 83 _ conflicts with, and thereby undermines, those precise goals and principles of Marco Civil. 


\section{A. Goals Relating to Access to the Internet}

Access to the Internet in Brazil is currently a privilege. Less than half of the Brazilian population has access to the Internet. ${ }^{84}$ The extent of Internet exclusion in Brazil is particularly alarming in some of its poorest and less educated regions, such as the North of Brazil, with around 66 percent of population not having access to the Internet. ${ }^{85}$

In recognition of the importance of promoting Internet access as a means for economic and social inclusion, Marco Civil establishes that Internet regulation in Brazil shall rest on the following principles and goals: "the preservation of the participatory nature of the Internet," 86 "promot[ion of] the right of accessing the Internet," 87 and "promot[ion of] access to information, knowledge and participation in cultural activities and public affairs." 88 However, Marco Civil also identifies network neutrality as a fundamental principle, failing to recognize that access to the Internet and the participatory nature of the Internet are threatened by imposing an "equal treatment" rule and a ban on access tiering.

As I explained in Part V, by prohibiting ISPs from offering tiered services to content providers, an "equal treatment" rule would raise the price of Internet subscriptions for end users and deny broadband access to marginal consumers. In Brazil, those marginal consumers tend to have lower incomes and less education. There is no basis in economic theory to presume that it would be socially optimal for end users - who are price-sensitive - to pay for the entire cost of building a highspeed broadband network while the companies that deliver content or applications to those same end users over the network - and therefore derive substantial economic advantage from its use--pay nothing.

A ban on access tiering would lower economic welfare. It would shift the cost burden of QoS enhancements to end users and thereby decrease broadband penetration and positive network effects. The proposed "equal treatment" rule would thus undermine the right of access to the Internet and the participatory nature of the Internet for Brazilian consumers - who should be the primary focus of this regulatory debate.

\section{B. Freedom of Speech and the Free Flow of Information}

In recognition of the importance of the Internet in furthering the constitutional rights of freedom of speech and the free flow of information, Marco Civil establishes that Internet regulation in Brazil shall be based on the principle of "safeguarding freedom of speech, communication, and manifestation of thought, in the terms of the Constitution." 89 Paradoxically, though, prohibiting content providers from purchasing enhanced QoS would impede growth in broadband access and decrease the positive network effects of the Internet. Network neutrality would thus limit the constitutional right of freedom of speech and the free flow of information. 
Network neutrality rules would further undermine those freedoms by exacerbating network congestion. Electronic communications are converging onto a single platform, the Internet protocol (IP) platform. ${ }^{90}$ The use of single protocol to transport heterogeneous types of traffic has enabled the simplification of complex telephone and data networks, ${ }^{91}$ as well as the integration of different types of content that were previously separate, such as voice and video. It has also created significant challenges to combat network congestion and maintain efficient Internet traffic flow.

Sharing of infrastructure means that congestion created by one type of traffic can impair the QoS of other traffic — thus creating a negative externality. ${ }^{92}$ Typical effects of network congestion include queuing delay. Different content and applications have different QoS needs. Real-time content is far less tolerant of latency or jitter than email is. ${ }^{93}$ Proponents of an "equal treatment" regime would ban prioritization or management of packets altogether. They assume that prioritization of one packet would discriminate against other packets and constrain the free flow of information in the Internet. They conclude there would be no net gain in social welfare from prioritization in the delivery of data packets.

However, social welfare from the Internet depends on consumption by human beings. Not all information that flows on the Internet is equally valuable to senders and recipients. It increases the economic welfare of society to deliver time-sensitive packets more quickly than time-insensitive packets. Management of packet delivery to address network congestion is a question of scheduling, not favoring some packets and "punishing" others. ${ }^{94}$

Network capacity is a limited resource. When a market for enhanced QoS is permitted to function, market-determined prices force suppliers of content and applications to internalize the full economic costs of network access. If, instead, an ISP were constrained to charge a price of zero to every content provider regardless of its need for enhanced QoS, then the result would be excess consumption of enhanced QoS. In other words, the result would be more network congestion. ${ }^{95}$

An "equal treatment" rule would eliminate mechanisms to mitigate congestion, thus worsening network congestion and degrading the quality of service for all content and applications, particularly for applications that are latency sensitive. This outcome of the "equal treatment" rule and the proposed ban on optional business-tobusiness transactions for enhanced QoS would limit the free flow of information on the Internet.

\section{The Goal "to Promote Innovation and Encourage the Dissemination of New Technologies of Models of Use and Access”}

The convergence of communication onto a single platform has transformed the Internet into a general purpose technology that supports many sectors across the 
economy. The Internet is increasingly becoming a platform for startups to quickly develop and bring to market new products and services. Boosting innovation in the Internet can play a central role for economic growth. ${ }^{96}$ Marco Civil upholds this potential, stating that Internet regulation in Brazil shall have the goal to "promote innovation and encourage the dissemination of new technologies and models of use and access." 97 Yet, Marco Civil's principle to safeguard network neutrality would undermine the goal to promote innovation.

\section{i. Reduced Investment at the Core and the Edges of the Network}

Permitting content and applications providers to voluntarily purchase from ISPs enhanced QoS will foster ISPs' development of next-generation broadband networks that support bandwidth-intensive content and applications. In contrast, an "equal treatment" rule would, among other things, force ISPs to operate inefficiently "dumb" networks incapable of distinguishing between delay-sensitive and non-delaysensitive traffic. Access tiering is key to innovation within the network and, contrary to the alleged by the proponents of an "equal treatment" regime, also fosters innovation at the edge of the network.

As mentioned above, the convergence of diverse electronic communications onto the IP platform raises the important question of how to manage traffic flow to minimize network congestion. Network congestion management represents additional costs to the ISP. It requires investment in engineering better network management practices and improving the capabilities of the network. It does not make sense to assume that such costs are fixed. To the contrary, one would anticipate that the ability of an ISP to enter into optional business-to-business transactions for enhanced QoS with content providers will affect the amount of investment that the ISP will make in capacity and efficient data handling.

To the extent that such agreements elicit more investment in such capacity than would otherwise be the case, it is plausible that even packets delivered over besteffort service will receive more resources under a regime that permits optional business-to-business transactions for enhanced QoS than under an "equal treatment" rule. ${ }^{98}$ Hence, a ban on access tiering would discourage ISPs from innovating in network management practices and in the capabilities of their networks.

By chilling innovation at the core of the network, network neutrality would chill innovation at the edges - in Internet content and applications. The benefits of innovation within the network redound in varying degrees to users at all levels — network operators, applications providers, and customers alike. ${ }^{99}$ Optional business-to-business QoS transactions enable ISPs to invest in QoS functionality enhancements. By improving the quality of the network, optional business-to-business transactions for QoS foster investment by content providers in technologies that benefit from enhanced QoS. 
If ISPs are prohibited from offering enhanced QoS choices, then the performance of latency-sensitive applications could deteriorate, and end users' satisfaction and demand for those applications could decline. Consequently, the expected profitability of innovations in content could be jeopardized - thus discouraging innovation. By harming innovation at the core, an "equal treatment" rule would harm innovation at the edges.

\section{Reduced Product Differentiation}

Optional business-to-business transactions for QoS are fundamentally a form of product differentiation. The ability to offer enhanced QoS creates another dimension over which ISPs can compete in their supply of broadband access. The ability of content providers to purchase enhanced QoS allow them to invest in new, differentiated products that benefit from enhanced QoS. Such transactions increase economic welfare because they foster product differentiation of content and applications and increase consumer choice, thereby increasing welfare for both consumers and producers of content and applications.

In dynamic markets like the Internet, innovation is greater under conditions of heterogeneous production choices and consumer tastes than under uniform production choices and consumer tastes. Diverse consumer demand in content and applications fosters innovation of differentiated products, as content providers seek to tailor their products to various consumer tastes. ${ }^{100}$ Within a heterogeneous setting, business opportunities abound and new entry is facilitated.

In contrast, with less product heterogeneity, there is a greater likelihood of the winner-take-all outcomes that proponents of network neutrality claim to fear. The "equal treatment" rule would actually increase the likelihood of sustained monopolistic or oligopolistic outcomes in the supply of content and application by discouraging entry by new content providers. To entice customers and advertisers away from the incumbent content providers, an entrant needs to offer a differentiated and superior Internet experience. One way to do so is to offer consumers and advertisers new real-time applications. As explained, a ban on purchasing enhanced QoS - which support innovative real-time applications - would thwart such product differentiation. The restricted ability of entrants to differentiate their products would discourage entry and investment in Internet content. ${ }^{101}$ It would increase the entry barriers of upstart content providers, thereby serving as incumbent protection for the large content providers. ${ }^{102}$

In short, a ban on access tiering would undermine the goals of Marco Civil related to fostering innovation and dissemination of new products and services. If ISPs are prohibited from offering enhanced QoS choices, then the performance of latency-sensitive applications could deteriorate, end users' satisfaction and demand for those applications could decline, and the viability of innovative business models used 
by both incumbents and entrants could be jeopardized. By harming innovation at the core, an "equal treatment" rule would harm innovation at the edges and increase the likelihood of sustained monopolistic or oligopolistic outcomes in the supply of content and application. It would discourage entry by upstart content providers, further limiting the potential inclusiveness of the Internet.

\section{D. "The Preservation and Safeguarding of Net Neutrality"}

A specified principle of Marco Civil is "the preservation and safeguarding of net neutrality."103 Brazilian network neutrality proponents seek to uphold this principle through the application of "equal treatment" to all data packets as a key component of regulating the Internet. However, an "equal treatment" rule conflicts with the other set of goals and principles of Marco Civil_ that is, promoting access to the Internet, protecting the constitutional rights of free speech and the free flow of information, and promoting innovation - as well as with the principle of inclusiveness of the Internet. Thus, as a matter of logical consistency, if one is to adhere to the latter goals and principles, one cannot give any weight to the notions of "equal treatment" and the preservation of network neutrality.

\section{CONCLUSION}

Proponents of network neutrality in Brazil seek to impose ex ante prohibitions on the actions of ISPs in the form of an "equal treatment" regime, which would constrain an ISP's behavior vis-à-vis providers of content and applications. The objectives of doing so are to spur content providers to innovate more, to deter ISPs from harming competition in the provision of content and applications, and to prevent threats to consumer's "Internet freedoms."

Because end users and content providers have complementary demand for access to the Internet, network operators already have the incentive to foster innovations in content and applications. Furthermore, permitting content providers to purchase enhanced QoS would contribute to ISP's recovery of sunk investments in the innovation of their networks, which would allow them to reduce prices to consumers-who should be the primary focus of this regulatory debate in a country with large degree of income inequality like Brazil. By permitting optional transactions for enhanced QoS, policymakers would also reduce negative externalities such as network congestion. Moreover, Brazilian antitrust law and Brazilian telecommunication legislation already address anticompetitive conduct and provide tailored remedies.

Policymakers considering regulation of broadband networks must consider unintended consequences of their proposals. In this case, implementing an "equal treatment" rule would have the opposite effect of that desired. It would undermine 
the goals and principles of Marco Civil to promote consumer's "Internet freedoms," the free flow of information, innovation, and inclusiveness of the network. It would benefit ISPs, Internet content providers, and, most importantly, consumers in Brazil for the network neutrality principles and the "equal treatment" requirements in Marco Civil to be removed.

: ARTIGO APROVAdO (02/12/2012) : RECEBIDO EM 16/11/2012

\section{NOTAS}

* Chairman, Criterion Economics, L.L.C., Washington, D.C.; Ronald Coase Professor of Law and Economics, Tilburg Law and Economics Center (TILEC), Tilburg University, The Netherlands. Email: jgsidak@criterioneconomics.com. Copyright 2012 by J. Gregory Sidak. All rights reserved.

1 See Lawrence Lessig, The Internet Under Siege, 127 Foreign Pol'y 56 (2001).

2 Id. at 56.

3 See Organization for Economic Cooperation and Development, Network Neutrality: A Policy Overview (2006).

4 See Lessig, supra note 1; Lawrence Lessig, The Future of Ideas: The Fate of the Commons in a Connected World (Random House 2001); Lawrence Lessig, Congress Must Keep Broadband Competition Alive, Fin. Times, Oct. 18, 2006; Lawrence Lessig \& Robert W. McChesney, No Tolls on the Internet, Wash. Post, June 8, 2006, at A23; Net Neutrality, Hearing before the Sen. Comm. on Commerce, Science, and Transportation, 109th Cong., 2d Sess. 59 (2006) (testimony of Lawrence Lessig), available at http://www.lessig.org/blog/archives/Lessig_Testimony_2.pdf.

5 Tim Wu, Network Neutrality, Broadband Discrimination, 2 J. Telecomm. \& High Tech. L. 141 (2003).

6 For example, as I elaborate below, the Brazilian proponents of a network neutrality regime have echoed the assumptions put forward by these law professors in support of network neutrality regulations in Brazil.

7 Christopher S. Yoo, Beyond Network Neutrality, 19 Harv. J.L. \& Tech. 1 (2005); Christopher S. Yoo, Network Neutrality and the Economics of Congestion, 95 Geo. L.J. 1847 (2006).

8 See, e.g., William J. Baumol, Martin Cave, Peter Cramton, Robert Hahn, Thomas W. Hazlett, Paul L. Joskow, Alfred E. Kahn, Robert Litan, John Mayo, Patrick A. Messerlin, Bruce M. Owen, Robert S. Pindyck, Scott J. Savage, Vernon L. Smith, Scott Wallsten, Leonard Waverman \& Lawrence J. White, Economists' Statement on Network Neutrality Policy (AEI-Brookings Joint Center Working Paper No. RP07-08, Mar. 2007), available at http: / / papers.ssrn.com/sol3 / papers.cfm?abstract_id=976889\#PaperDownload.

9 See Declaration of Gary S. Becker \& Dennis W. Carlton, In the Matter of Preserving the Open Internet, Broadband Industry Practices, GN Dkt. No. 09-191, WC Dkt. No. 07-52 (filed with the FCC on behalf of Verizon Jan. $14,2010)$.

10 See id. 
11 See Richard A. Epstein, Net Neutrality at the Crossroads, FT.Com, Oct. 27, 2009, available at http://www.ft.com/cms/s/0/d9611768-c310-11de-8eca-00144feab49a.html?nclick_check=1.

12 See Statement of Alfred E. Kahn, Robert Julius Thorne Professor of Political Economy, Emeritus, Cornell University, before the FTC Workshop on Broadband Connectivity Competition Policy (Feb. 13, 2007), http://www.ftc.gov/opp/workshops/broadband/presentations/kahn.pdf (Feb. 21, 2007 rev.).

13 See Bruce M. Owen, Antecedents to Net Neutrality, 30 REG. 14 (2007); Bruce M. Owen \& Gregory L. Rosston, Local Broadband Access: Primum Non Nocere or Primum Processi? A Property Rights Approach, in Net Neutrality or Net Neutering: Should Broadband Internet Services be Regulated? 163 (Thomas M. Lenard \& Randolph J. May eds., 2006).

14 J. Gregory Sidak, The Impact of Multisided Markets on the Debate over Optional Transactions for Enhanced Delivery over the Internet, 7 Politica Económica y Regulatoria en Telecomunicaciones 94 (2011); J. Gregory Sidak \& David J. Teece, Innovation Spillovers and the "Dirt Road"Fallacy: The Intellectual Bankruptcy of Banning Optional Transactions for Enhanced Delivery over the Internet, 6 J. Competition L. \& Econ. 521, 526 (2010); J. Gregory Sidak, A Consumer-Welfare Approach to Network Neutrality Regulation of the Internet, 2 J. Competition L. \& Econ. 349 (2006); Senate Testimony of J. Gregory Sidak on Network Neutrality Regulation, Hearing Before the Senate Committee on Commerce, Science, and Transportation, 109th Cong. 59 (2006).

15 Sidak \& Teece, supra note 14.

16 Bill No. 2126/2011. See Câmara dos Deputados, Projeto de Lei 2126/2011, available at http://www.camara.gov.br/proposicoesWeb/fichadetramitacao?idProposicao=517255/.

17 To date, Congressman Alessandro Molon, key sponsor of the Bill, has attempted three times without success to introduce the final version of the Bill to vote. See Câmara dos Deputados, Projeto de Lei 2126/2011, available at http://www.camara.gov.br/proposicoesWeb/fichadetramitacao?idProposicao=517255/.

18 See Fundação Getulio Vargas, Direito RJ, Contribuição do Centro de Tecnologia e Sociedade da FGV ao Debate sobre Neutralidade de Rede no âmbito do Marco Civil da Internet (June 15, 2012), available at http: / / observatoriodainternet.br/wp-content/uploads/2012/06/Contribuicao-do-CTS-FGV-sobre-neutralidade-derede-no-Marco-Civil1.pdf.

19 Id.; Google, Facebook e Mercado Livre Lançam Carta Aberta a Favor do Marco Civil da Internet, Convergência Digital, Sept. 18, 2012, http://convergenciadigital.uol.com.br/cgi/cgilua.exe/sys/ start.htm?infoid $=31830 \&$ sid $=4$.

20 Getulio Vargas, Direito RJ, supra note 18.

21 See Alessandro Molon, Statement of Congressman Alessando Molon, before $3^{\circ}$ Seminário de Proteção à Privacidade e aos Dados Pessoais (Oct. 2, 2012), available at http://www.teletime.com.br/02/10/2012/molonacredita-que-marco-civil-ja-esta-maduro-e-podera-ser-votado-em-outubro/tt/303762/news.aspx [hereinafter Statement of Molon].

22 See Uol/Diveo, Statement of UOL/Diveo, before Seminário TELETIME Broadband (June 29, 2011), available at http://www.teletime.com.br/29/06/2011/neutralidade-de-redes-e-defendida-mas-com-ressalvas / tt/229786/news.aspx.

23. Id.

24 Fundação Getulio Vargas, Direito RJ, supra note 18; Instituto Brasileiro de Defesa do Consumidor (IDEC), Statement of IDEC (July 26, 2012), available at http://www.idec.org.br/em-acao/em-foco/idec-vai-aporto-alegre-debater-relatorio-do-marco-civil-da-internet; IDEC, Statment of IDEC, Fundação Getulio Vargas, Direito RJ, Intervozes (Aug. 07, 2012), available at http://www.idec.org.br/ckfinder/userfiles/files/ DocumentodeApoio_MarcoCivil_07ago12.pdf; ABRINT, Statement of ABRINT (Sept. 20, 2012), available at http://convergenciadigital.uol.com.br/cgi/cgilua.exe/sys/start.htm?infoid=31872\&sid=4.

25 Getulio Vargas, Direito RJ, supra note 18. 
26 Id.; ABRINT, supra note 24.

27 See, e.g., Arthur Barrionuevo, Statment of Arthur Barrionuevo, before ABTA 2012 (July 2012), available at http: / / www.telaviva.com.br/01/08/2012/especialistas-discordam-do-conceito-de-neutralidade-de-rede-e-do-papeldo-cgi/tl/292059/news.aspx; Telebrasil, Statement of Telebrasil, before 56 PainelTelebrasil, (Aug. 29, 2012), http://www.telaviva.com.br/29/08/2012/valente-destaca-preocupacao-das-teles-com-regras-deneutralidade/pt/296357/news.aspx; Telebrasil, Statement of Telebrasil, before 56 PainelTelebrasil (Aug. 30, 2012), available at http://www.advivo.com.br/blog/marcelosoaressouza/para-teles-neutralidade-de-rede-prejudica-modelode-negocio; Cisco, Statement of Cisco (May 30, 2012), available at http://itweb.com.br/57856/neutralidade-da-redepode-inviabilizar-cloud-computing-e-proprio-acesso-a-web-diz-cisco.

28 See sources in supra note 27.

29 Monica Tavares, Marco Civil da Internet só Será Votado Depois das Eleições, Clipping (Sept. 20, 2012), https: / / conteudoclippingmp.planejamento.gov.br/cadastros/noticias/2012/9/20/marco-civil-da-internet-so-seravotado-depois-das-eleicoes.

30. Bill No. 2126/2011, art. 3, 4 .

31 Id. art. 9.

32 See, e.g., David S. Evans, The Antitrust Economics of Multi-Sided Platform Markets, 20 Yale J. on Reg. 325 (2003); Jean-Charles Rochet \& Jean Tirole, Platform Competition in Two-Sided Markets, 4 J. Eur. Econ. Ass'n 990 (2003).

33 See Interview with Alessandro Molon, Teletime: Um Marco para a Internet, 15 Teletime (Apr. 2012), www.teletime.com.br/4/2012/um-marco-para-a-internet/tt/281239/revista.aspx; Getulio Vargas, Direito RJ, supra note 18; Inimai M. Chettiar \& J. Scott Holladay, Free to Invest, The Economic Benefits of Preserving Net Neutrality (N.Y.U. Sch. of Law Institute for Policy Integrity, Report No. 4, Jan. 2010).

34 Nicholas Economides, Why Imposing New Tolls on Third-Party Content and Applications Threatens Innovation andWill Not Improve Broadband Providers' Investments, GN Dkt. No.09-191, WC Dkt. No. 07-52 (filed with the FCC on behalf of Google Jan. 14, 2010).

35 Sebrae, Acesso a Serviços Financeiros, Carta Convite para Tecnova, http://www.sebrae.com.br/ atender/customizado/uasf (last visited Nov. 13, 2012).

36 See Sidak \& Teece, supra note 14 , at 547.

37 PricewaterhouseCoopers/National Venture Capital Ass'n, Investment by Industry Q3 '12, MoneyTreeTM Report, Data: Thomson Reuters (Sept. 19, 2012), available at http://www.nvca.org/index.php?option= com_docman\&task=cat_view\&gid= $57 \&$ Itemid $=317$.

38 See Sidak\& Teece, supra note 15 , at 548.

39 Economides, supra note 34 , at 6.

40 See Teleco, Estatísticas BL (Oct. 18, 2012), http://www.teleco.com.br/blarga1.asp (showing the average speed of broadband in Brazil).

41 See Bradley Mitchell, How Fast Does Your Network Need To Be?, About.com, http://compnetworking.about.com/od/speedtests/tp/how-fast-does-your-network-need-to-be.htm (last visited Nov. 3, 2012).

42 See Voip-info.org, Bandwidth Consumption, http://www.voip-info.org/wiki/view/Bandwidth+consumption (last visited Nov. 5, 2012);

43 Id. 
44 Game applications typically demand the fastest connections. See, e.g., GCFLearnFree.org, How to Choose an Internet Service Provider, http://www.gcflearnfree.org/computerbasics/extra/91 (last visited Nov. 3, 2012) ("The fastest connections (greater than $\sim 3 \mathrm{Mbps}$ ) benefit serious gamers and users who are regularly sending and receiving large files.”).

45 In fact, Internet users worldwide, including in Brazil, have been increasingly enjoying faster Internet speed. See, e.g., Cisco, Barômetro de Banda Larga no Brasil, 2005-2010, at 18 (2006), available at http://www.cisco.com/ web/BR/barometro/barometro_2006.pdf; Cisco, Hiperconectividade e a Aproximação da Era dos Zetabytes, at 15 (June 2, 2010), available at http://www.cisco.com/web/BR/assets/docs/Cisco_Hyperconnectivity_ebook_0610_PB.pdf; Cisco, Cisco Visual Networking Index, 2009-2014 (June 2, 2010), available at http://www.cisco.com/ web/BR/assets/docs/Cisco_VNI-Methodology_WP_June2010_PB.pdf.

46 Joseph Farrell \& Phil Weiser, Modularity, Vertical Integration, and Open Access Policies: Towards a Convergence of Antitrust and Regulation in the Internet Age, 17 Harv. L.J. \& Tech. 85, 89 (2003).

47 See Lessig \& McChesney, supra note 4.

48 See Statement of Molon, supra note 21

49 See Teleco, BL Fixa: Oi Lidera em Market Share, Net e GVT em Crescimento (Apr. 14, 2012), http://www.teleco.com.br/comentario/com467.asp.

50 Farrell \& Weiser, supra note 46, at 101.

51 See Investimentos de Telecom no Brasil Alcançaram R\$ 4,7 Bilhões no Primeiro Trimestre, UOL, June 18, 2012, http: / / computerworld.uol.com.br/telecom/2012/06/18/investimentos-de-telecom-no-brasil-alcancaram-r-4-7bilhoes-no-primeiro-trimestre/.

52 See Getulio Vargas, Direito RJ, supra note 18; ABRINT, supra note 24.

53 See Investimentos de Telecom no Brasil Alcançaram $R \$ 4,7$ Bilhões no Primeiro Trimestre, supra note 51.

54 Farrel \& Weiser, supra note 46.

55 See, e.g., Internet Preço varia até 100\% em Salvador, Kade Conquista, Oct. 11, 2010, http://www.kadeconquista.com/v1/2010/10/11/internet-preco-varia-ate-100-em-salvador/.

56 See Sidak \& Teece, supra note 14, at 531.

57 These centers usually have platform competition between both cable modem and DSL, and sometimes even between three different platforms. In addition, many of these centers have more than three players offering broadband service. See, e.g., Internet Precovaria ate 100\% em Salvador, supra note 55.

58 Brasil Lançará Satélite para Levar Banda Larga a Todo País, diz Ministro, Uol, Mar. 28, 2012, http:// tecnologia.uol.com.br/ultimas-noticias/afp/2012/03/28/brasil-lancara-satelite-para-levar-banda-larga-a-todopais.jhtm; Wimax Pode Desligar Parabólicas do Brasil, Info, July 13, 2011, http://info.abril.com.br/noticias/tecnologiapessoal/wimax-pode-desligar-parabolicas-do-brasil-13072011-23.shl.

59 The data include mobile Internet and fixed Internet. See Brasil.gov.br, Programa Nacional de Banda Larga Comemora dois Anos e Aponta Mercado em Crescimento (May 14, 2011), http://www.brasil.gov.br/noticias/arquivos/ 2012/05/14/programa-nacional-de-banda-larga-comemora-dois-anos-e-aponta-mercado-em-crescimento.

60 Id.; Veja Lista das 100 Cidades que Terão Banda Larga Ainda em 2010, Diálogos Políticos, Aug. 26, 2010, http: / / dialogospoliticos. wordpress.com/2010/08/26/veja-lista-das-100-cidades-que-terao-banda-larga-ainda-em2010-segundo-telebras/.

61 Acesso à Banda Larga no Brasil Cresce 74\% Em um Ano, Estado de São Paulo, June 21, 2012, http://economia.estadao.com.br/noticias/economia,acesso-a-banda-larga-no-brasil-cresce-74-em-um-ano, 116840,0.htm; 
Internet no Brasil, Estamos Evoluindo?, Artigonal, Dec. 1, 2011, http: //www.artigonal.com/internet-artigos/internet-no-brasilestamos-evoluindo-5447104.html; Cisco, Barômetro de Banda Larga no Brasil, 2005-2010, supra note 45, at 18-19.

62 See sources in supra note 61.

63 The data include fixed Internet and satellite. See Cisco, Banda Larga no Brasil, 2005-2010, supra note 45, at 11.

64 The data include fixed Internet. See Teleco, Estatísticas BL, supra note 40 (showing broadband accesses and SCM in Brazil).

65 Cisco, Visual Networking Index, The Zettabyte Era, http://www.cisco.com/en/US/solutions/collateral/ ns341/ns525/ns537/ns705/ns827/VNI_Hyperconnectivity_WP.html.

$66 I d$

67 See id.

68 Brazilian Antitrust Law, Lei No. 12.529, de 30 de novembro de 2011 (Brazil), available at http: / / www.cade.gov.br/Default.aspx?5aed3ccd27fc13101a27015ef3.

69 See, e.g., Brazilian Telecommunications Law, Lei No. 9.472, de 16 de julho de 1997 (Brazil), available at http://www.planalto.gov.br/ccivil_03/leis/L9472.htm.

70 GVT Home Page, http://www.gvt.com.br/portal/home/index_cidades.jsp (last visited Nov. 3, 2012).

71 See Sidak \& Teece, supra note 14, at 563.

72 In economic terms, the price (more precisely, the markup above marginal cost) for products sharing common cost should be based on the inverse elasticity of demand. See, e.g., Harvey Rosen, Public Finance 334 (McGrawHill Irwin 7th ed. 2005).

73 World Bank Data, Income Share Held by Lowest 20\%, http://data.worldbank.org/indicator/ SI.DST.FRST.20/countries?order=wbapi_data_value_2009+wbapi_data_value\&sort $=$ asc (last visited Nov. 2, 2012).

74 World Bank Data, GINI Index, http://data.worldbank.org/indicator/SI.POV.GINI?order= wbapi_data_value_2009+wbapi_data_value\&sort=asc (last visited Nov. 2, 2012). The Gini index measures "the extent to which the distribution of income or consumption expenditure among individuals or households within an economy deviates from a perfectly equal distribution." Id.

75 The seminal paper in the literature on network effects is Jeffrey Rohlfs, A Theory of Interdependent Demand for a Communications Service, 5 Bell. J. Econ. \& Mgmt. Sci. 16 (1974).

76 See, e.g., Massimo Motta, Competition Policy: Theory and Practice 82 (Cambridge Univ. Press 2004); Lester D. Taylor, Telecommunications Demand in Theory and Practice 9 (Kluwer Academic Press 1994); Bridger M. Mitchell \& Ingo Vogelsang, Telecommunications Pricing: Theory and Practice 11 (Cambridge Univ. Press 1991); Jean Tirole, The Theory of Industrial Organization 405 (MIT Press 1988); Stanley J. Liebowitz \& Stephen E. Margolis, Network Effects, in 1 Handbook of Telecommunications Economics 76 (Martin E. Cave, Sumit K. Majumadar \& Ingo Vogelsang eds., 2002).

77 See, e.g., Milton L. Mueller, Jr., Universal Service: Competition, Interconnection, and Monopoly in the Making of the American Telephone System (MIT Press \& AEI Press 1997).

78 Marco Civil, art. 4, I "to promote the right of accessing the Internet" and "to promote access to information, knowledge and participation in cultural activities and public affairs"); id. Article 3, VII ("the preservation of the participatory nature of the Internet").

79 Id. art. 3, I ("safeguarding freedom of speech, communication, and manifestation of thought, in the terms of the Constitution"). 
80 Id. art. 3, I ("safeguarding freedom of speech, communication, and manifestation of thought, in the terms of the Constitution").

81 Id. art. 4, III ("to promote innovation and encourage the dissemination of new technologies and models of use and access").

82 Id. art. 3, IV ("the preservation and safeguarding of net neutrality").

83 Id. art. 9 (" $[\mathrm{t}]$ he party responsible for the transmission, switching or routing of data has the obligation of granting equal treatment to every data package, with no distinction by content, origin and destination, service, terminal or application").

84 Instituto Brasileiro de Geografia e Estatística (IBGE), Pesquisa Nacional por Amostra de Domicílios de 2011 [National Survey by Household Sampling of 2011] (Sept. 21, 2012), available at http://www.ibge.gov.br /home/estatistica/populacao/trabalhoerendimento/pnad2011/default.shtm (stating that approximately 55 percent of the Brazilian population lacks Internet access).

85 Internet Ganha 9,9 mi de Usuários no Brasil em 2 Anos, Aponta IBGE, Terra, Sept. 21, 2012, http://tecnologia.ter ra.com.br/noticias / 0, , O I 6169465 - E I 12884,00 Internet + ganha + mi + de+usuarios + no + Brasil+em + anos + aponta+IBGE.html.

86 Marco Civil, art. 3, VII.

87 Id. art. 4, I.

88 Id. art. 4 , II.

89 Id. art. 3, I.

90 The Internet protocol network is a packet-switched network that sends information in packets. Rather than having to remain open for one stream of data for the entire duration of the data transmission, a given portion of bandwidth can accommodate numerous streams of data simultaneously. See Sidak \& Teece, supra note 14 , at 533 .

91 IBM Global Technologies, Business Benefits of Converged Communications (Oct. 2006), available at http://www-935.ibm.com/services/uk/igs/pdf/converged-communications-pov_ 0906.pdf.

92 See J. Gregory Sidak, A Consumer-Welfare Approach to Network Neutrality Regulation of the Internet, 2 J. Competition L. \& Econ. 349, 360-61 (2006).

93 See Sidak \& Teece, supra note 14, at 533.

94 Id. at 534.

95 In other words, they would disregard the costs to the network of supplying enhanced QoS, including the opportunity costs of reducing shared bandwidth available for other content that may have a greater need for enhanced QoS to create greater social value - as price signals would have shown, had they been allowed.

96 James Manyika \& Charles Roxburgh, The Great Transformer: The Impact of the Internet on Economic Growth and Prosperity, McKinsey Global Institute, Oct. 2011, http://www.mckinsey.com/insights/mgi/research/ technology_and_innovation/internet_matters.

97 Marco Civil, art. 4, III.

98 See Sidak \& Teece, supra note 14, at 535.

99 Id. at 538 
676 : THE FALLACY OF "EQUAL TREATMENT" IN BRAZIL'S BILL OF RIGHTS FOR INTERNET USERS

100. Id. at 540 .

101. Id. at $454-55$

102 Google, Facebook e Mercado Livre Lançam Carta Aberta a Favor do Marco Civil da Internet, supra note 19.

103 Marco Civil, art. 3, IV.

J. Gregory Sidak

1000 Connecticut Avenue N.W., Suite 900 Washington, DC 20036 jgsidaklacriterioneconomics.com
Chairman, Criterion Economics, L.L.C., Washington, D.C. Ronald CoAse Professor of LaW and ECONOMics, Tilburg Law and Economics Center (TILEC), TILBURg UnIVERSITY, THE NetherLANDS 